\title{
The Expectation for Risk-Sharing Cycle: Theoretical Model and Global Implementation
}

\author{
Ishay Wolf \\ ${ }^{a}$ Cordoba University, Spain, Lorena Caridad y Lopez Del Rio, Cordoba University, Spain
}

Article History: Received: 10 November 2020; Revised 12 January 2021 Accepted: 27 January 2021; Published online: 5 April 2021

\begin{abstract}
In this paper, we offer an explanation to pension systems cyclical reforms, based on Central East Europe (CEE) countries experience over the last three decades. We claim that in the transition to funded pension design, the government not only transfers longevity and fiscal risks to the individualbut also absorbs risks transferred from the public, where each market actor transfers undiversifiable risks to the other. This hidden risk path that has not been discussed yet in the literature, stemmed from the public expectation to risk premium or adequate old age benefits that evolves to political pressure. The outcomes of this risk path realized in financial transfers, such as social security, means-tested and minimum pension guarantee. Consequently, funded pension designs naturally converge to a new landscape paradigm of risk sharing, including intergenerational and intra-generational play. Financial crises such as the recent COVID-19 pandemic foster the convergence process.
\end{abstract}

Keywords: social security, pension, risk, minimum pension guarantee, political pressure, adequacy, pension reform

\section{Introduction}

Since the 1990s, countries around the globe have introducedpension structural reforms, moving from the public pay-as you-go (PAYG) defined benefit(DB) model toindividual accounts in a multipillar architecture (Ebbinghaus2015). The main reason was and still is fiscal constriction as of low fertility and longer period at retirement. Governments, particularly in aging Europe, could not obligeanymore to adequate pension level in PAYG DB schemes without raising taxes (Holzmann and Hinz2008). This entailed diverting funds from the public pension system into individually funded accounts.

However, in many countries, these reforms were short-lived. At the onset of the global economic crisis, most countries that had adopted pension privatization reforms either halted them, drastically reduced the private element, or completely abandoned them (Arza 2012; Naczyk and Domonkos 2016; Orenstein 2013; Sokhey 2017). The financial market crash in 2008 has challenged the merits of private funded pensions as their assets experienced a substantial decline within a short time(Grech 2018; Altiparmakov 2018). Consequently, over the last decades, the trust in the sustainability of the new pension pillar system has been shattered (Ebbinghaus 2015).

In practice, pension privatization did not deliver the expected results. Coverage rates decreased, pension benefits deteriorated, and gender and income inequality increased, making reforms unpopular (Guardiancich 2017; Grech 2018). The increased role of supplementary pension funds and the recent economic and financial downturn have led to new challenges in relation to both the future financial sustainability and the adequacy of pension benefits. Now it is clear that the direction of pension reforms appears to have changed again, with a considerable number of countries reversing the policies they adopted in the 1980s and 1990s (Arza 2008; Ebbinghaus 2015; Mesa Lago and Valero2020; Barr and Diamond 2016).

The literature on risk sharing in pension schemes has started to emerge with the privatization wave and the continuous debate on the balances pension design. Some papers are more analytical and examine the efficient allocation of funded pension fund and the individual savings (Goiller 2008) and some papers focus on the government roll and adequate benefits level (Natali 2009; Hinrich 2015; Oliviera and Ponomarenko 2017). This strand of literature claims that the growing role of defined contribution (DC) funded pensions may leave individuals exposed to wide variety of risks, threaten consumption in oldage. The common individual cannot manage these risks by themselves. The late examples for that are the financial crisis in 2008 and the COVID-19 pandemic crisis, in which governments have been obligated to provide enormous rescue and social plans to their citizens. Nobody ever expected the individual tomanage these buckets of risk alone withintheirpersonal pension account. In most cases, the average individual is not even aware of those risks (Randle and Rudolph 2014).

Another strand of literature has examined the pension systems processes across Eastern Europe and LatinAmerica, as countries in these regions started to roll back from DC pension scheme to a PYA DB pension 
scheme with an unstable landscape. Many of them present a variety of reasons forthe reversals-political, fiscal stress, and more (for example, Natali 2018; Altiparmakov 2018; Zandberg and Spierdijk 2013).

This composition contributes to these two strands of literature by pointing to a bi-pathways flow of risks among the government and the public, while shifting to a more funded pension scheme. We ask if funded pension schemes entail a risk path from the public to the government in addition to the familiarshifting of risks from the government to the individual. We claim that the mutual expectations ofrisk sharing among the public and the government will eventually determine an equilibrium of pension pillars sizes, where each actor tries to shift to the other undiversifiable risks.In fact, we link theabove-mentioned reasons of reversals in CEE and Latin Americacountries to a lack of risk-sharing mechanisms between the government and the public. The gap results in political pressure and eventually cyclical pension reforms.

We further argue that economic shocks, such as the financial crisis in 2008 and lately the COVID-19 pandemic crisis may foster this process, as the risks were realized faster.

After developing the theory of risk sharing expectations between the government and the individual, in the second part of this paper, we demonstrate this theory on the experience of CEE countries pension reversals.

In the next section, we describe the mutual risk-sharing model in funded pension funds. In Section 3, we detail the opportunities of risk sharing from the individual to the government. We define the levels of government intervention in the market as risk sharing 'Orders'. We argue that the probability to another pension reform depend on the efficiency of these orders. We review different risks, financial,personal and structural risks that are being diversified through risk-sharing orders. Section 4 demonstrates the implementation of risk-sharing orders in pension systems reversals across CEE countries, as part of the converge process toward equilibrium among actors in the field. Section 5 discusses the linkage between the risk-sharing theory to CEE countries' pension experience. Section 6 provides conclusions.

\section{The Cycle Scheme}

During pension transition to a more funded, capitalized one, the government transfers undiversified fiscal risks to individuals. This fiscal risk translates to a variety of risks on the individual's pension portfolio and triggers a risk-sharing cycle.

\subsection{The Government's Expectations}

The main difference between DB and DC schemes comes from the exposure to different types of risks, and how these risks are allocated between employer, employee, plan sponsor and the government (Rappaport and Peterson 2014). Any change in the pension system affects the risk-sharing framework and bearsbalance of risk ensemble among actors.

In pension schemes, the government is considered as a mediator actor among different participants' generations and different field actors (Tausch et al. 2013). However, since the government has other public spending every year $(G)$ and fiscal constraints, it desires to lower pension spending and minimize its risks. Transition to funded pension scheme enables the government to lower the first pillar size (social security) and to redirect taxes to finance other public needs (Espin-Andersen 1990).

\subsection{The Individual's Expectations}

The individual expects to be able to retainhis standard of living in old age in any pension scheme and to avoid poverty (Kuitto and Kuivalainen 2020). From the individual perspective, the fiscal risk transition translated to a bucket of risk for families, such as longevity risk, market risk, solvency risk, asymmetric information risk, career risk, and systemic risk. Some of the risks have been transferred directly from the government, such as longevity risk and some from the system change, such as market risk. From the individual's point of view, the source of the risk is not important but his ability to diversify it.

In the analogue to the capital asset pricing model (Markowitz 2010), the individual expects a risk premium for the risks he cannot diversify. The market risks arethe most intuitive example.The individual benefits from the opportunity to gain from the market exposure in excess of the former pension scheme (Goiller 2008).However, what is the risk premium to exposure to longevity risk or to asymmetric information risk?

Based on global experience, as will be discussed in the second part, we argue that expectationsforrisk premium evolves to political pressure and pension reversals or structural changes (Altiparmakov 2018). If a system is not seen as beneficial by the electoral majority, namely if it doesnot helpthem maintain their pre-retirement living standards, it could be voted out (Bradley et al. 2016; Grech 2018). 
After this process, the risk premium can address many forms, including increasing the social security financial transfers, imposing minimum pension guarantee, and even government obligation to an adequate benefit level (Mabbett 2020; Altiparmakov 2018; Mesa Lago and Valero 2020).

The benchmark for the individual benefit expectation is not clear. We assume that the former PAYG DB benefit level is only a theoretical reference point. The expectations depend on a personal and general variety of variables, such as risk appetite and the peer group pension benefits at retirement.Political pressure can arise due to disappointing form pension benefits, or if the performances are relative to the previous generations or compares to previous market conditions (for example, the streets demonstrations in Greece in 2012, in Lebanon in 2019, and France in 2019).

\subsection{Pension Market in Equilibrium}

Summing up the balance of interests in the pension market:

- The individual expects a risk premium in addition to the expected benefit from the funded fund scheme. The individual uses political pressure to increase the risk premium to a satisfactorylevel.

- The government wish to decrease its fiscal obligations and its future fiscal risks.

Figure 1 demonstrates the balance mechanism toward an equilibrium of pension benefit. From one side, the government transfers fiscal risk and changes the pension system to a fundedcapitalized one. In the same line, the government tries to cut fiscal transfers to the individual.From the other side, the public expects risk premium on the excess of risks theycould not diversify or transferontheirbehalf.This risk sharing process converged to an equilibrium of benefits and risks.

\section{Figure 1:}

\section{Individual Expectation of Pension Benefit}

\section{Benefit After the Transition}

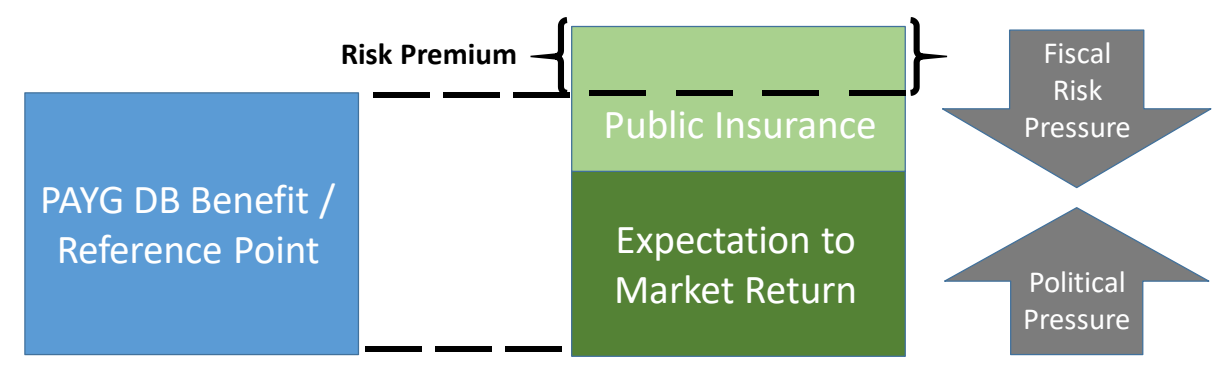

Source: Authors' Elaborations

These expectations are not equal among the public cohort. The importance of diversification is most significant for low and middle earning cohorts. While high-earning cohorts have usually other sources of assets and savings apart from the pension scheme, low and middle earning cohorts are leaning heavily on old-age pension benefits (Tausch et al. 2013). Additionally, low earning cohorts have fewer resources to diversify risks. These cohorts are vulnerable and will be hit hard in situations of recessions, when the systematic risk may be realized and when the compensations of market returns are not high enough to cover economical theoretical loss from periods without significant contributions during the career phase.

Here, we claim that the income inequality level in the market affects the pension equilibrium above. Since the government transfers the risks to the individual, the opposite risk sharing depends on the actor's strength. As more individuals are in close financial situation, the individual becomes stronger against the government and the probability to a pension reversal increases.

\section{Risk-Management Processes}

In this subsection, we overview the risk-sharing mechanism in which each side transfers undiversifiable risks to the other party. Pension plan designs range from those that place virtually all of the risk on the plan, such as traditional PAYG DB design to those that place nearly all the risk on the individual covered by the plan DC scheme. Neither is ideal (Rappaport and Peterson 2015) and no model is superior (Barr 2006). 
We refer to three levels of government intervention in the market, or 'orders'. These orders can be considered as an opposite pathway of risks from the individual back to the government.

\subsection{The 1st Order: Pension Risk Sharing by Market Design}

Countries choosing to base their pension systems on private funds must first have well-established financial markets, as well as adequate public and government understanding and mutual trust (Bohn 2010). From one side, the government transfers fiscal risk and longevity risk to the public and changes the pension system (Leisering2003). On the other side, the government is obligated for operations in market design, which enables efficient capitalized pension accumulations in personal portfolios. Regulation and governance enable diversifying market failures (Grech2018). The individual is not capable managing inherent market failures/risks and transfer those to the government responsibility.We overview the main pension risks that are managed and shared by a healthy market design:

\section{A. Longevity Risk}

When shifting from DB scheme, the government transfers longevity risk to the public. The outcome is sensitivity to low fertility and average life expansion in the form of higher contributions and lower old age benefits. Regulation and market design enable risk-pooling in the annuities market (Reichling and Smetters 2015). An annuity creates a redistribution ex-post, as some individuals die early and forfeit their resources to those who die later. In that form, individuals, through plan sponsors, can manage idiosyncratic mortality risk additionally, by enabling annuity market, the individual shares this risk with his same age cohort.

\section{B. Asymmetric Information}

This market failure risk includes insufficient regulatory and transparency, fiduciary risk, undeveloped financial infrastructure, or imperfect information regarding the labor market and the insurance companies. Many individuals do not have the motivation, knowledge, or skill to provide a satisfactory retirement income on their own. Many DC participants will not have adequate benefits at retirement because contributions are too little, or they haveusedthe money too early or have not earnedenough investment income due to overly conservative or poorly timed decisions. Member individuals did not manage these kinds of risks before pension reforms and need advisory and trust in the central planner (Bohn 2010).

Naturally, transition of pension system depends onsustainablemarket infrastructure, which can enable the individual the opportunity to pool these risks with others and to make rational decisions(Leisering 2003). Clearly, these two risk families are supposed to be managed in the macro level by government agencies and regulation, as the individual is too small to influence the system(Einav et al., 2010;Adams et al. 2010).Figure 2 describes the risk spectrum as function of government/individual's risk bearing. The red color signifies high risk bearing, whereas the green color indicates the possibility fordiversification of risk to the respective actor. Yellow color indicatedriskbearing in some level. Respectively, when the pension design moves from the pure DC scheme with actively central planner market design, the individual's risk bearing change to yellow instead of red.

Figure 2:

\begin{tabular}{|l|c|c|c|c|c|}
\hline \multicolumn{7}{|c|}{ Panel A: Risk Sharing by Market Design } \\
\hline $\begin{array}{c}\text { Actor } / \\
\text { Government } \\
\text { Intervention Scale }\end{array}$ & Pure Funded DC & $\begin{array}{c}\text { 1st Order: Market } \\
\text { Design and } \\
\text { Regulation }\end{array}$ & $\begin{array}{c}\text { 3rd Order: } \\
\text { 2nd Order: } \\
\text { Mix Scheme } \\
\text { Min Scheme + } \\
\text { Guarantee }\end{array}$ & DB PAYG \\
\hline Government & Low & Low & Low & Low & High \\
\hline Individual & High & \multicolumn{3}{|c|}{ Risk Pooling } & Low \\
\hline
\end{tabular}

\section{Fiscal Risk}

As was revealed in the financial crisis in 2008 and again nowadays during the COVID-19 pandemic global crisis, in times of recession, the government need fast and available financial resources. In a systemic global crisis, this money tends to be expensive, as risk premiums soars and the government is forced to raise money in open market with higher interest rates (Bielawska 2015). Eventually, the public would have to bear the interest rate costs. A loan from savings from pension funds wealth is hence a win-win solution among the government and the public. These monetary resources could have been invested in national infrastructure projects to wake economies with high return and with close supervision of government agencies. Instead, in times of macroeconomic shocks, it might absorb drastic drops in the financial markets. 
A mixedpension scheme with substantial public scheme can be a fiscal instrument for the government in raising capital to foster economic activity during recessions and ease weaker cohorts' consumption, without weakening its long-term viability (Barr and Diamond 2009). Consequently, in our color model, from the government perspective in pure DC scheme, some may argue that the color should be yellow and not green.

\subsection{The 2nd and the 3rd Orders: Intergenerational and Intra-generational Risk-Sharing}

If the individual is capable to manage their pension account in an efficient market and the first order is valid, we turn to manage accumulations risks along their working phase. We define the second order as the implementation of social security and the third order as public social transfers, such as means-tested programs and implementation of minimum pension guarantee.These mechanisms are socio-economic transfers from the government to the individual. The governmenttries to minimize fiscal risk by transitioning to funded-privatized pension scheme in the first place (Holzmann et al. 2008). Hence, the government hedges social security fiscal risk by intergenerational risk sharing (Hardy 2020). The diversification of social security mechanism is held by redistribution among adjacent generations as part of the unfunded PAYG feature.The third order augments and intensifies the second order's risks diversification effect. This order includes implementation of target pension, means-tested or minimum pension guarantee. The third order involves a mix of intergenerational and intragenerational risk-sharing mechanisms.Learning from global experience, governments around the world with funded schemes make efforts to impose automatic modifications of these mechanisms (Natali 2018).

The government income redistribution mechanism enables diversifying mainly financial risks and wage/carrier risks, which cannot be managed in the individual's portfolio by themselves(Mabbett 2020). These kinds of risks are, naturally, much more critical for weak cohorts, as they do not have enough resources to diversify or managerealizations of these risks.

Imposing minimum pension guarantee, as part of the third order, deepen diversification of personal and financial risks, which can be realizeddue to wrong decisions along the individual's career path, economic shocks, or systemic risk. Meaning, it may provide a safety cushion in times of recession when strong correlation between wage reduction and unemployment are realizedwith capital market fall (Antolin et. al. 2011).

\section{A. Market Risk}

Unfunded pillar and / or minimum pension guarantee is uncorrelated to capital markets and is being a cushion against market falls. Many countries operate rate of return minimum pension guarantee in funded pension schemesforthat reason (Marx 2016; OECD 2019).In times of financial crisis, such as in 2008 and the COVID-19 pandemic crisis, which includes realizations of correlations between risks-financial, personal, or systemic risk, we witnessed a significant rise in the government transfers.

\section{B. Solvency Risk}

Workers in occupational pension schemes receive their current and future income from the same source, and therefore are highly dependent on their employer, suffering a 'double blow' if the company enters bankruptcy. Portfolio theory argues that efficient risk bearing requires sufficient diversification across assets classes and individual issuers. Yet, it may be difficult for employees to diversify the risk posed by their current and future income coming from a single source (Zaidi2010).

As pointed in Figure 3, in government DB plans, we assume there is no risk to the individual, as the government credit risk is higher, by definition, than any insurance company. In DC plans, however, individual participants bear most of the solvency risk if the financial institution or particular investment funds become insolvent. As government intervention deepens and larger fraction of benefits depends on public benefits, solvency risk reduces.

\section{Wage / Career Risks}

Wage / career risks in a family is correlated to the individual's choices and fortune along theircareer and at the end of theirworking phase. Due to the accrued effect in funded pension schemes, the continuity of working is highly significant to adequate pension benefits.Government social transfers, which are not correlated completely to the individual's wage path, might diversify these kind of risks onsome level, as providing economic cushion for old age. In that case, the government participates in that risk up to some level.

\section{Labor Market Distortions}

Social security and minimum pension guarantee may alleviate labor distortions risk. One can consider the employer's contributions to social security / pension guarantee as part of the differed wage that is ensured by governmental deposit. Hence, the justification for governmental pension benefit schemes is providing a layer of security for beneficiaries against a sponsor's bankruptcy and therefore compensate for any asymmetric 
information and correct any market failure (Tausch et al.2013). They can be seen as credit cushion where the individual is not capable in assessing theiremployer bankruptcy risk. In that case, the employer contributions are in fact 'differed wage'.

Figure 3 points to a 'mirror' risk sharing position between the individual and the government. As studied above, the government's fiscal spending diversifiesthe above risks in some levels. Practically, the government as a mediator, participates in risk bearing through the instruments of social security and minimum pension guarantee. The effectiveness of these orders is higher with low correlations between government transfers and wage(Grande and Visco 2010). That is essential in times of realizing tail risk and for the weak earning cohorts who have not enough wealth and knowledge to diversify that risk with their own portfolios.

Figure 3:

\begin{tabular}{|l|l|l|l|l|l|}
\hline \multicolumn{7}{|c|}{ Panel B: Classic Bidierctional Risks Flow } \\
\hline $\begin{array}{c}\text { Actor / } \\
\text { Government } \\
\text { Intervention Scale }\end{array}$ & Pure Funded DC & $\begin{array}{c}\text { 1st Order: Market } \\
\text { Design and } \\
\text { Regulation }\end{array}$ & $\begin{array}{c}\text { 3rd Order: } \\
\text { 2nd Order: } \\
\text { Mix Scheme }\end{array}$ & $\begin{array}{c}\text { Mix Scheme + } \\
\text { Minimum Pension } \\
\text { Guarantee }\end{array}$ & DB PAYG \\
\hline Government & Low & & & & High \\
\hline Individual & High & & & & Low \\
\hline
\end{tabular}

The minimum pension guarantee is unique by its risk sharing effect. It can be financed by the state budget (intergenerational risk sharing) or with differentiation on the first pillar benefits allocation (intergenerational + intragenerational risk sharing). This means retirees cannot receive higher benefits than the contributions collected and fair value accumulation (Grande and Visco 2010). However, this is all true to the sum-up level. The intergenerational diversification between young and old and intragenerational diversification entail that there is notalways a direct bond between contributions and benefits.

\section{The Experience of Convergence toward Pension Design Equilibrium}

\subsection{Why CEE Countries?}

In this section, we demonstrate converging process to risk-sharing equilibrium in funded pension schemes. A large number of pension reforms were designed and driven by the WorldBank, based on the argument of the impending crisis of aging and its impact on the sustainability of pension systems (e.g. World Bank, 1994). While Western European countries with matured public pay-as-you-gosystems have dismissed pension privatization initiatives. Most profound and extensive pension reforms took place in the 1990s in Latin America and Eastern Europe (Bielawska 2015).

Between 1981 and 2018, 29 countries undertook pension reforms, introducing either partial privatization or full privatization with individual accounts and private administrations (Altiparmakov 2018). However, 19countries, 13in Eastern Europe and 6in Latin America reversed privatization, that is $60 \%$ of the countries that had privatized pension reversed privatization. Five othercountries in Latin America have strengthened the zero pillar of minimum pension guarantee (Mesa Lago and Valero2020).

Here, we focus on CEE countries reversals from risk sharing orders perspective. While every country case is specific and needs to be assessed in its context, the implementation of risk-sharing mechanismshascommon elements in the configuration of the new pension systems during pensions the re-reforms wave. Specifically, the literature finds common characteristics in the following CEE countries history of cyclical pension reforms: Russia, Latvia, Estonia, Bulgaria, Croatia, Latvia, Lithuania, Kazakhstan, North Macedonia, Poland, Hungary, Czechia, Romania, Slovakia, and Slovenia

Empirical evidence shows that these reforms failed to deliver the improvements that were initially propagated by the World Bank (1994). Coverage rates stagnated or decreased, pension benefits deteriorated, and gender and income inequality increased (Fultz and Hirose 2019). The financial crisis severely affected financial and capital markets, significantly reducing the real value of private pension assets and, consequently, causing popular outrage with the results of the private system. The risk of financial market fluctuations was left to pensioners. Many pensioners had to rely on social support as the value of their pension benefits had fallen to very low levels, often below the poverty line. Moreover, administrative costs further reduced pension benefits and workers' 
participation in management was eliminated (Ebbinghaus 2015). In section 3we explain that in lack of riskdistributions mechanisms. Consequently, political risks push decision takers to reverse back to PAYG schemes.

However, when compared to CEE countries reforms to funded pension designs, most Western high earning countries in Europe still implement dominant first pillar in the form of DB PAYG pension scheme (see Figure 4). According to the OECD annual report (OECD 2019), most of the pension reforms in advanced countries can be summed in parametric changes, such as consistently raising the retirement age and adapting contribution rated with no drastic reforms or reversals. The relative stable pension landscape in advanced countries is due to a balance between fiscal needs and the system's generosity (Fultz and Hirose 2019). Thatcome to realize through liberal markets, competitive as well assophisticated financial private sector and high government regulation. These inherent mechanisms may diversify asymmetric information, market distortions, and provide available and efficient instruments hedging financial risks through capital markets (Zaidi 2010).

Figure 4: Dominant pension schemes across Europe -

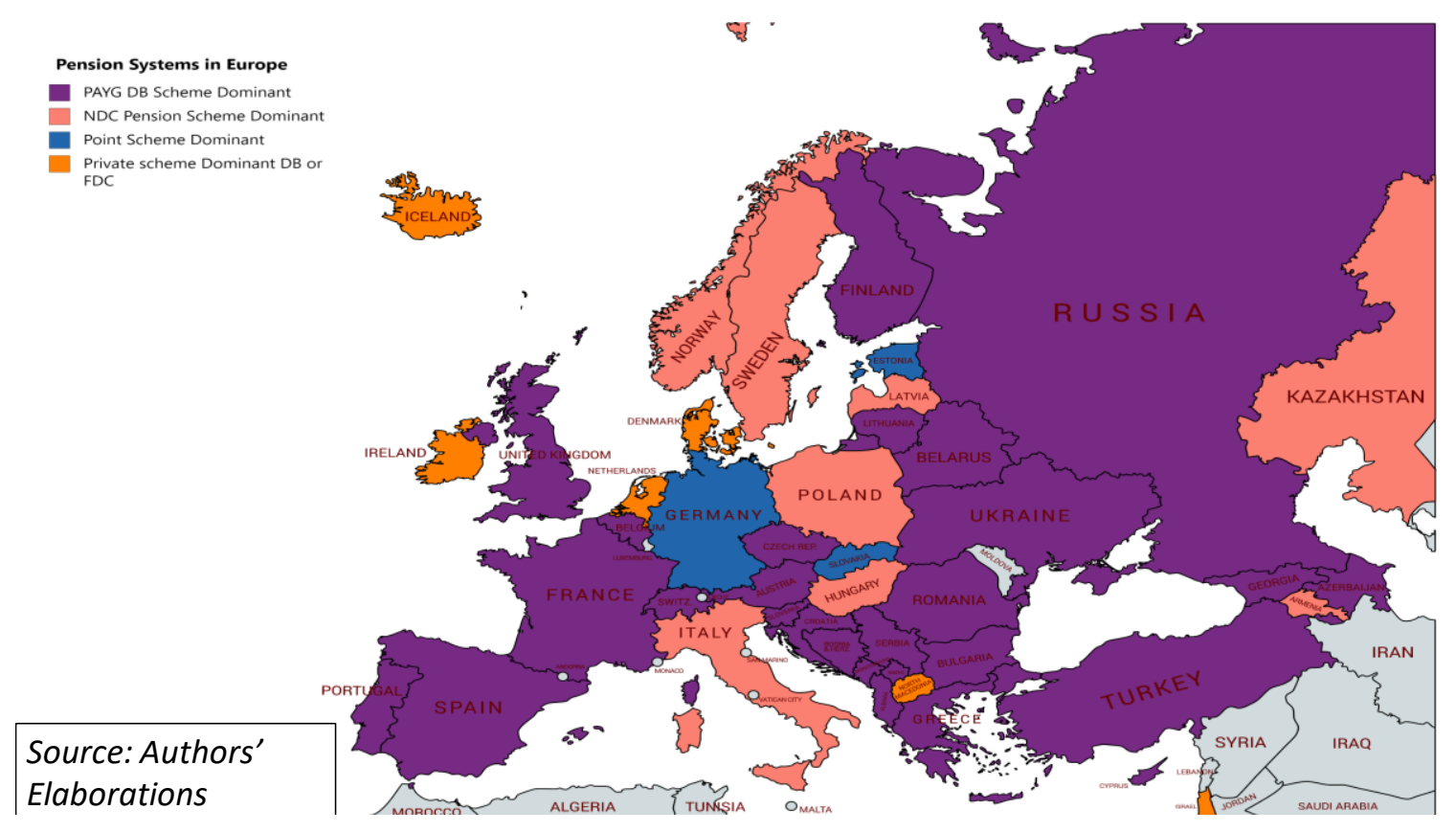

\subsection{Lack of the 1st Risk-Sharing Order}

CEE countries in the 1990 s were out of the communist regime and capital markets were still lacking supervision and mutual trust. Guardiancich (2010) claims that in Poland, for instance, private fund supervision went through continuous organizational changes and took almost ten years to develop but remained riddled with inefficiency and excessive politicization. Inadequate consulting and marketing practices, early withdrawal penalties and low tax incentives, as well as crowding out by the first pillar, prevented voluntary pensions from expanding. Undeveloped markets cause inefficient investments and high volatility and risk for participants (Munnell and Quinby, 2009).

We show how pension reversals substantially improve market design, regulation, and governance. Over the years, government intervention created trust among actors after the soviet regime with more transparency and efficiency in the private funds' operations.

Many European governments maintained a 'voluntarist approach' to organizing private welfare provisions until well into the 1990s. This implies that the allocation of occupational and personal welfare benefits was left to 'private initiative' (see Esping-Andersen, 1990). Lack of governance in designing pension reforms realized when many CEE governments(Croatia, Estonia, Latvia, North Macedonia, Poland, and Slovakia) launched their 2nd pillar before they defined in law the benefit package that workers could expect to receive (Fultz and Hirose, 2019).

The major design problems in most of the privatization reforms have been replaced by a centralized public administration. Governments improve adequate policy formulation and related decision-making processes. The rereforms reinforced the government role in the administration, regulation, and supervision of the pension systems. Most of the countries after re-reforms, such as Poland, Hungary, and Kazakhstan created autonomous bodies for the regulation and supervision of private pensions (Mesa-Lago and Valero, 2020). 
The experience in CEE countries also revealed the problem in the budget risk transfer. According to the evidence, the reforms during the 1990s failed to deliver an improvement in fiscal and financing terms and financing the transition toward individual accounts exacerbated pre-existing fiscal pressure in most countries (Altiparmalov,2018).The mix of pillars ease fiscal stress for enough time to foster economic activity and to socially ease low earning cohorts during deep recession and decreasing overall debt. Governments were able to invest part of the nationalized funds in public developments projects (e.g. nuclear power electricity plants, roads, trains, public housing etc.).Thetarget was to create positive multiplier effects with regard to public revenues, such as taxes and social security contributions (Hujo and Rulli, 2014).

\subsection{Lack of the 2nd and the 3rd Risk-Sharing Orders}

An interesting indicator of healthy intergenerational risksharing in pension is the transition of the poverty rate from the old to the young. Between the mid-1990s until the end of 2016,most of the European countries improvedthepoverty rate in old-agewith regard to the entire population across Europe (see Figure5). Here, we point that across some ofthe CEE countries, however, the trend is the exact opposite, as old-age poverty has increased. That may indicate insufficient risk-sharing mechanisms inherent in pension systems and one of the reasons of political pressure to conduct re-reforms.

Alarge variety of improvement rates inold-age poverty in the sample countries stem from the timing and the intensive rate of imposing pension privatization reforms and reversals. For example, the improvement of relative old-age poverty rate in Slovenia may be attributed to the abolishing of the 2 nd pillar as part of the re-reforms. And the improvement in Slovakia to imposing late partial privatization-capitalization pillar with a small 2nd pillar, which has operated for only threeyears until the reversal. In both of the cases, the 3rd order might haveplayed an important role.

Figure 5: Poverty shift in Europe: Aged over 65 vs. 18-25 -

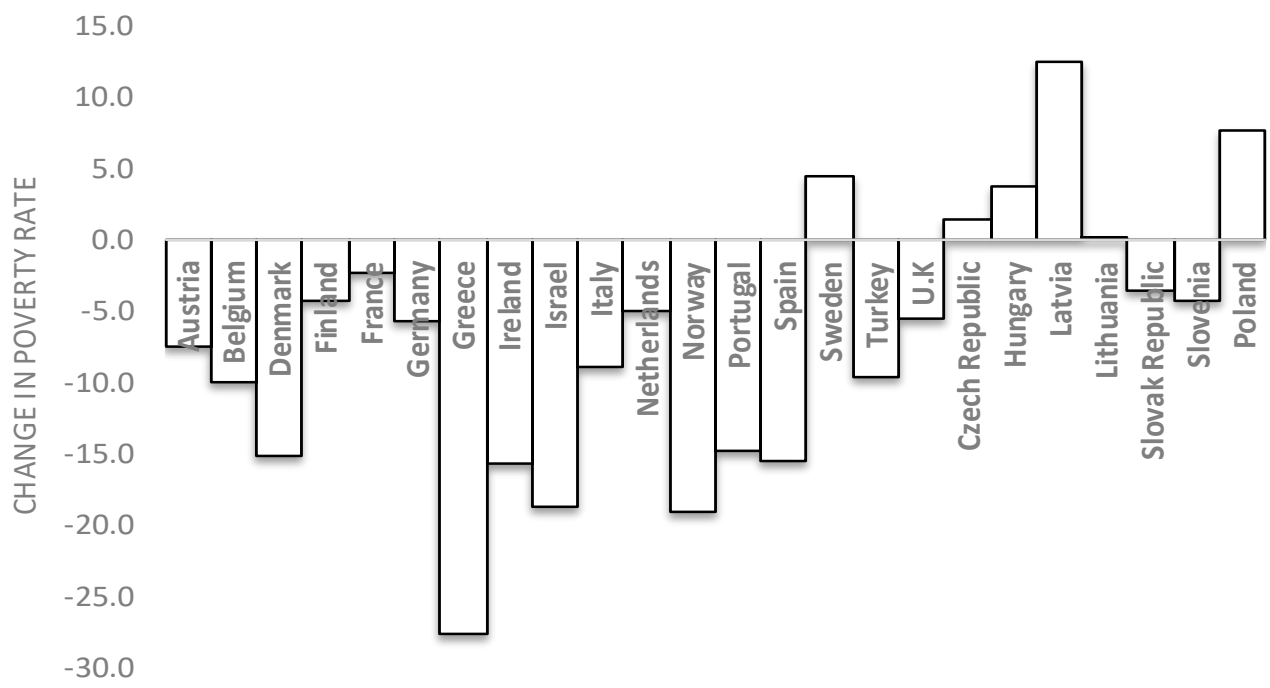

Source: Based on OECD/Pension at Glance, 2019

In Figure 6, we point to a convergence process of implementing minimum pension guarantee or target pension after pension reform reversals. In red color, we have the CEE countries that have been through pension reform during the 1990s and made reversal. These countries are compared to Western countries in Europe, colored in yellow, which implement target or minimum pension guarantee.

In the appendix, we overview the main reversal of CEE countries according to the definitions of the risk sharing orders. All analyzed countries have been re-balancing their radical reforms since the 1990s and early 2000s by implementing 2nd and the 3rd risk-sharing orders and recognizing public social insurance. Furthermore, they redesigned social security based on the principles of social solidarity, redistribution, and shared responsibility for pension provision among actors (Fultz and Hirose 2019; Marchal et al. 2014).

Pension systems' re-balancing was done by various methods:

- Increasing 1st pillar contributions in the expense of the 2nd pillar-Poland, Bulgaria, Latvia, Lithuania, Czechia

- $\quad$ Providing individuals the option to reverse back to the 1st pillar of public pension and social security from the 2nd pillar (private funded funds) — Bulgaria, Croatia, Hungary and Slovakia 
- Imposing minimumpension guarantees and intergenerational diversifications-Hungary, Poland, Czechia, Slovakia, Latvia, Slovenia and Kazakhstan.

Figure 6: Implementation of minimum pension guarantee in Europe

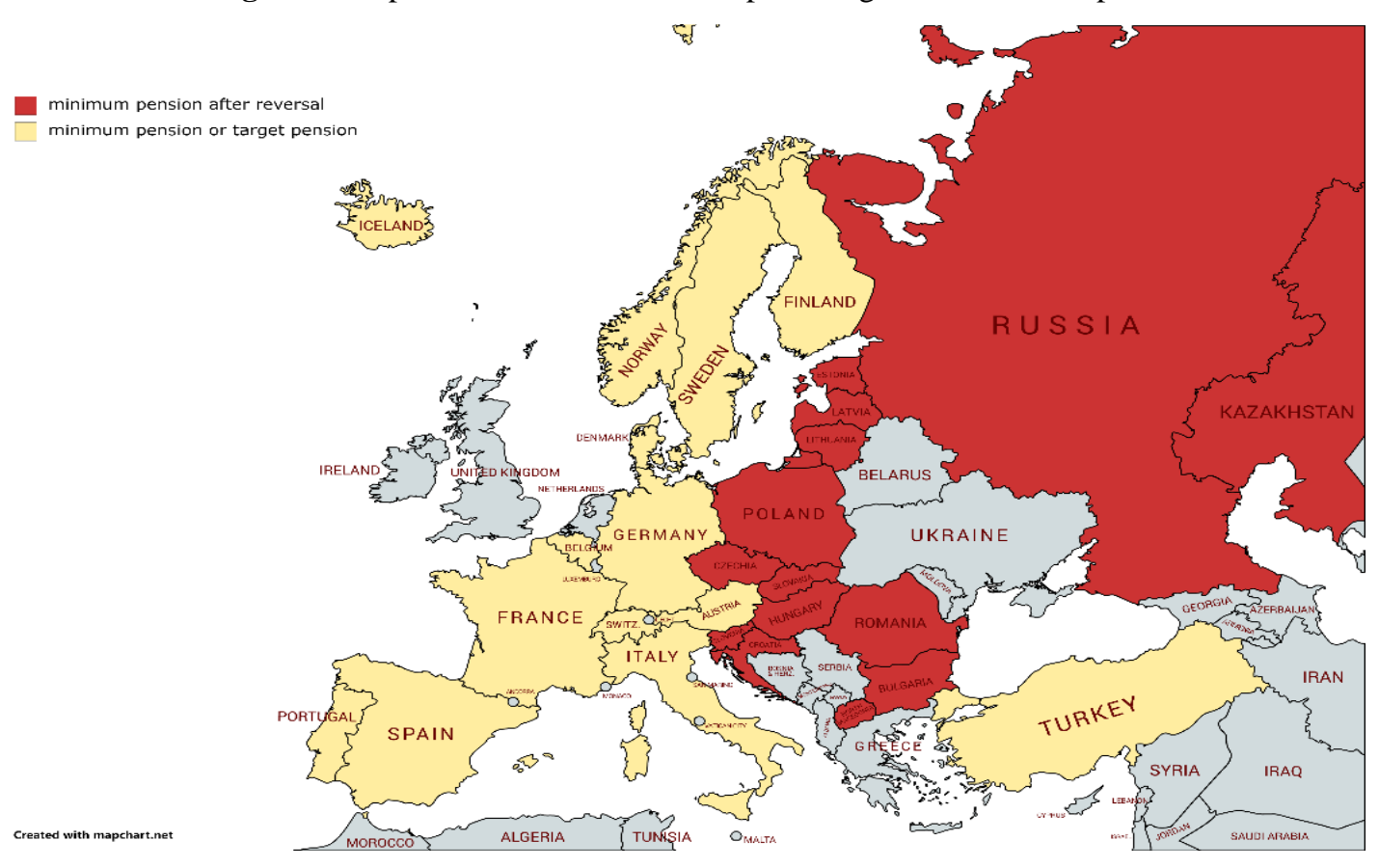

\section{Discussion}

There is little doubt that successfully 'averting the old-age crisis' in Eastern Europe will need to involve private pension funds. However, their funding, operations and interactions with other public pension pillars will need to resemble successful practices in developed countries instead of relying on the radical World Bank (1994) reform blueprint.

The comparison between Western countries and CEE countries experience demonstrates that when the pension market is pre-mature and unregulated, the public seek other financial risk mechanisms. That may lead to political pressure focus on governmental transfers, such as increasing social security and imposing minimum pension guarantee. This process explains the deviation in market designs among the different countries, which choose funded-capitalized pension scheme, dealing with the same challenges of low fertility, longevity, and fiscal risks.

Nowadays, we still identify continuing reversal process even a decade after the financial crisis, such as in Romania (2018) and Croatia (2019), including the learning process, which is reflected in the comprehensive pension design that includes risk-sharing mechanisms to improve and sustain their pension systems.

Given the political economy of reforms, the large voting power of people nearing or beyond retirement age might mount again to recalibrate public pensions and to regulate private pensions (Munnell and Quinby2009). Indeed, the literature recognizes that imposing a minimum pension guarantee is an important condition to any transition to a more funded-capitalized scheme, in order to assure sustainability of pension schemes and make them politically acceptable (Marx 2016). Almost all actual reform proposals have guaranteed current law scheduled benefits (Antolin et al. 2011). Pension guarantee is becoming more and more required in the volatile markets.

According to the above, it is not surprising to notice a globalshifting trend in implementing mechanisms of minimum pension guarantee (Lachance et al. 2003; Arza2008). Guarantees in DC schemes have recently become more common, especially in Latin America, which has been at the forefront of pension privatizations (Mesa-Lago and Valero 2020). Those countries join stable pension economies across Europe, which implement minimum pension guarantees, such as Finland, Germany, Italy, Switzerland, Greece, Spain and Portugal.

This suggests that policymakers are moving somewhat beyond the narrow interpretation of pension system sustainability that was adopted in previous decades. They realize there are potential feedback effects on overall fiscal outlays from the impact of reductions in pension system generosity and that if reforms leave a system unable to fulfill its goals, the possibility of policy reversals becomes quite probable. 


\section{Conclusion}

The aim of this paper is to discuss the bi-path ways of risks in funded pension schemes. Here, we illuminate a hidden risk shifting that was less studied, from the individual back to the government.

This composition has stressed key dimensions of the complex public/private relationships and has drawn attention to aspects of risk sharing between different periods and among different earning cohorts. In all of which the government plays a significant role as a central planner and as a mediator.

Consequently, financial torments strengthened the position of domestic opponents of pension privatization by highlighting private pension funds' disputed macroeconomic effects and their volatile returns.After re-reforms of pension schemes in the last 15 years, more governments understand that the 1990 s reforms were not coherent enough (Natali 2018; Ebbinghaus 2015). Over the last three decades, the experience in CEE and Latin America countries havedemonstrated convergence to an equilibrium pension design. In those pension designs, the government recognizes its responsibilities in the risk-sharing framework and acts to diversify some of the traditional individual's risks. The recent financial crisis due to the COVID-19 pandemic confirms this process, as we are witness to large bailout governmental programs due to political pressure. The global public assistance to the pension market and labor markets emphasize the individual's inability to bear high fluctuations in the market for long, mainly duringold age or when close to retirement.

Policy analysis that focuses on a single objective, such as fiscal strengthwill be flawed. One should understand that there is no single perfect design, and the solution depends mostly onthe policy objectives and the underline economy.

The implication of this study is the continuity of this trend of cyclical reforms in other countries that have base their pension systems on funded benefits, such as in USA, Great Britain, Israel, or Iceland. Financial crisis will probably foster this breathing process as the public expects the government to participate on the risk. In this context, it is worthwhile to implement the above 'Risk-Sharing Orders Model' on Notional Defined Contribution (NDC) pension scheme, which was adapted by several countries,such as Poland, Latvia,and Kazakhstan (Bielawska2015). High poverty and inequality rates in these countries imply insufficient risk-sharing mechanisms (Barr, 2006) thatmight cause another wave of pension re-reforms in these countries.In comparison to Norway, Sweden, and Italy, which implement the NDC scheme, there is a need forstrong and mature markets and governance that is much more sophisticated and regulations to implement NDC schemes (Barr, 2006). Hence, perhaps the timing of implementing NDC scheme in these countries is too early, where these countries are still undergoing major structural transition toward the market economy. Additionally, as financial and systemic shocks are accelerating public reaction, it will be interesting to examine the pension systems design sometime after the Corona-Virus crisis..

\section{References}

Adams W, Einav L, Levin J (2009) Liquidity Constraints and Imperfect Information in Subprime Lending. American Economic Review 99:49-84.https://doi.org/10.1257/aer.99.1.49

Altiparmakov, N (2018) Another look at causes and consequences of pension privatization reform reversals in Eastern Europe. Journal of European Social Policy 28(3):224-241. https://doi.org/10.1177/0958928717735053

Antolin P, Payet S, Whitehouse E, Yermo J (2011) the role of guarantees in defined contributions pensions. The OECD library.

Arza K (2008) Pension reform in Latin America: Distributional principles, inequalities and alternative policy options. Journal of Latin American Studies 40(1):1-28.http://www.jstor.org/stable/40056624

Barr N (2006)Non-financial defined contribution pensions: mapping the terrain.In Pension Reform of Holzmannm R.The World Bank.https://doi.org/10.1596/978-0-8213-6038-5

Barr N, Diamond P (2009) Reforming pensions: Principles, analytical errors and policy directions. International Social Security Review 62(2):5-29.

Bielawska K (2015) Pension reforms and long-term sustainability of public finances of the central eastern European countries.In M Szczepański, M Szczepański (Ed), Social security systems in the light of demographic, economic and technological challenges : monograph (pp 21-32). Publishing House of Poznan University of Technology.

Bohn H (2010) Shouldpublic retirement plans be fully funded? Retrieved from Cambridge. http://doi.org/ $10.3386 / w 16409$

Ebbinghaus B (2015)Theprivatization and marketization of pensions in Europe: A double transformation facing the crisis.European Policy Analysis, 1(1):56-73.https://doi.org/10.18278/epa.1.1.5.

Einav L, Finkelstein A, Schrimpf P (2010) Optimal mandates and the welfare cost of asymmetric information: Evidence from the U.K. Annuity Market.Econometrica 78(3).https://doi.org/10.3982/ECTA7245 
European Commission (2010) Progress and key challenges in the delivery of adequate and sustainable pension in Europe.European Economy 71.Brussels: DG Economic and Financial Affairs.

Esping-Andersen G (1990)Threeworlds of welfare capitalism. Princeton, NJ: Princeton University Press. (ed) in Welfare States in Transition: National Adaptations in Global Economies. London: Sage.

Fultz E, HiroseK (2019)Second-pillar pensions in central and eastern Europe: Payment constraints and exit options. International Social Security Review 72(2019).

GrandeG, Visco I (2009) A public guarantee of a minimum return to defined contribution pension scheme members. Bank of Italy, Economic Research and International Relations Area No 762.

GoillierC (2008) Intergenerational risk sharing and risk taking of a pension fund.Journal of Public Economics 92:1463-1485.

Grech A (2018) Whatmakes pension reforms sustainable.Sustainability, 10(8).https://doi.org/10.3390/su10082891

Hardy M (2020)Diversification in retirement inequality, The Journals of Gerontology: Series B75(4, May 2020):

823-826. https://doi.org/10.1093/geronb/gbz147

Holzmann R, Hinz RP, Dorfman M (2008)Pension systems and reforms conceptual framework. Social Protection Discussion Paper 0824.

Kuitto K, Kuivalainen S(2020) Pension, in the Handbook on society and social policy, pp 279-290. https://doi.org/10.4337/9781788113526.00029

Leisering L (2003) From redistribution to Regulation-Regulating private provisions for old-age as a new challenge for the welfare state in aging societies.Paper presented at the 4th International Research Conference on Social Security, Antwerp, 5-7 May 2003.

Mabbett D (2020)Reckless prudence: financialisation in UK pension scheme governance after the crisis.Review of International Political Economy.https://doi.org/10.1080/09692290.2020.1758187

Markowitz H (2010) Portfolio theory as I still see it.Annual Review of Financial Economics2:123.https://doi.org/10.1146/annurev-financial-011110-134602

Marx I (2016)Raising minimum income floors: incrementalism and innovative pathways. Paper presented at the RC 19 Expansion and Retrenchment in Social Policy: North-South Dialogues Conference, San Jose.

Mesa Lago C, Valero D (2020) Thenew wave of pension reforms in Latin America. In Peris-Ortiz M., ÁlvarezGarcía J., Domínguez-Fabián I., Devolder P. (eds) Economic challenges of pension systems. Springer, Cham. https://doi.org/10.1007/978-3-030-37912-4_12

Munnell A,Quinby L (2009) pension coverage and retirement security. Issues in Brief ib2009-9-26, Center for Retirement Research, revised Dec 2009.

Natali D (2008) Pensions in Europe, European pensions.Brussels: PIE Peter Lang.

Tausch F et al. (2013) Preferences for redistribution and pensions. What can we lean from experience?Journal of Pension Economics and Finance12:299.

Rappaport A, Peterson A(2014) Risk-sharing alternatives for pension plan design: An overview and case studies.Wharton Pension Research Council Working Papers. 92.

Reichling F, Smetters K (2015)Optimalannuitization with stochastic mortality and correlated medical costs. American Economic Review 105(11): 3273-3320.doi:10.1257/aer.20131584

Republic of Bulgaria Report (2017) Country fiche on pension projections.Sofia, November 2017.

Zaidi A (2010) Sustainability and adequacy of pension in EU countries: Synthesis from a cross-national perspective.European Papers on the New Welfare 15:65-76 


\section{Appendix - CEE countries'pension reforms}

\begin{tabular}{|c|c|c|c|c|c|}
\hline \multicolumn{2}{|c|}{ Country } & Reform & Reversal & 2nd Order & 3rd Order \\
\hline 1 & Bulgaria & 2002 & 2007 & $\begin{array}{l}2014-2 \text { nd pillar account holders were } \\
\text { allowed to return to the } 1 \text { st pillar, while } \\
\text { refunding their account balances to the } \\
\text { government (this option is available until } 5 \\
\text { years before retirement); }\end{array}$ & $\begin{array}{l}2014 \text { - Minimum income support for the elderly is } \\
\text { provided through the state; } \\
\text { The minimum old-age pension amount is set every } \\
\text { year by the Public Social Insurance Budget Law; }\end{array}$ \\
\hline 2 & Croatia & 2002 & 2011 & $\begin{array}{l}\text { Retrenchments of private second pillar } \\
\text { mandatory pensions; Mandatory individual } \\
\text { account contribution reduced from } 10 \text { per } \\
\text { cent to } 5 \text { per cent }\end{array}$ & Relative rate of return guarantee for the snd pillar. \\
\hline 3 & Czechia & 2004 & 2016 & $\begin{array}{l}2016 \text { - Terminating individuals' accounts. } 1 \text { st } \\
\text { pillar dominant. }\end{array}$ & $\begin{array}{l}\text { Pension fund managers must guarantee the } \\
\text { nominal value of contribution made by plan } \\
\text { members every year. } \\
\text { Contributions cannot receive a negative rate of } \\
\text { return; }\end{array}$ \\
\hline 4 & Estonia & 2002 & 2009 & $\begin{array}{l}\text { The government suspend its contribution to } \\
\text { the second pillar; } \\
\text { Universal benefit component as part of the } \\
\text { first pillar; } \\
\text { Transition to a NDC pension scheme }\end{array}$ & \\
\hline 5 & Hungary & 1998 & $\begin{array}{l}2011 \text { - } \\
\text { Terminating } \\
\text { individuals' } \\
\text { accounts }\end{array}$ & $\begin{array}{l}2011 \text { - Nationalized private pension assets } \\
\text { individual and closed the } 2 \text { nd private pillar; } \\
\text { Transition to the treasury PAYG DB } \\
\text { mandatory scheme from the age of } 63.5+;\end{array}$ & $\begin{array}{l}\text { Minimum pensnion guarantee finances from the } \\
\text { state budget; } \\
\text { Mandatory pension funds must ensure that the } \\
\text { investments return is not less than } 15 \% \text { less than } \\
\text { the yield on Hungarian government bonds; } \\
\text { pension-tested benefit around } 103 \text { USD per month } \\
\text { (2018) and } 80 \text { USD means-tested (2013); }\end{array}$ \\
\hline 6 & Kazakhstan & 1998 & 2004 & $\begin{array}{l}2013 \text { - Consolidation of } 10 \text { private pension } \\
\text { funds into the public pension fund (UPF); } \\
\text { - Implementing PAYG DB financed by state's } \\
\text { budget and managed by the National Bank } \\
\text { of Kazakhstan; }\end{array}$ & $\begin{array}{l}2013 \text { - Reversal of privatization and intriduction of } \\
0 \text { Pillar: Basic Social Pension (BPP) } \\
\text { (unconditional, universal pension payment). The } \\
\text { zero pillar consists of the basic social pension } \\
\text { (BSP). All citizens who have reached retirement } \\
\text { age receive a BSP. The BSP is an equal amount } \\
\text { for all, regardless of work experience and salaries. }\end{array}$ \\
\hline 7 & Latvia & 2001 & 2009 & $\begin{array}{l}\cdot 2009 \text { - Individual account contribution } \\
\text { reduced from } 5.5 \% \text { to } 1.5 \% ; \\
\text { - In } 2016 \text { after stabilizing - gradual increase } \\
\text { to } 6 \% \text {; } \\
1 \text { st pillar diminant - NDC scheme. }\end{array}$ & $\begin{array}{l}2014 \text { - minimum income level of } 40 \% \text { of the } \\
\text { median income } 71-109 \text { EUR depends in } \\
\text { contribution period; } \\
2017 \text { - basic pension guarantee of } 64 \text { EUR a } \\
\text { month; }\end{array}$ \\
\hline 8 & Lithuania & 2004 & 2009 & $\begin{array}{l}2009-2019 \\
\text { Downsizing of ondividual accounts; } \\
\text { 1st pullar dominant - point scheme. }\end{array}$ & $\begin{array}{l}\text { Insurance as part of the point system by } \\
\text { contributions; }\end{array}$ \\
\hline 9 & Macedonia & 2006 & 2011 & $\begin{array}{l}\text { Contributions to mandatory individual } \\
\text { accounts reduced from } 7.42 \text { per cent to } 5.25 \\
\text { per cent and strengthening the first pillar. }\end{array}$ & \\
\hline 10 & Poland & 1999 & 2014 & $\begin{array}{l}2014 \text { - Terminating indivudal accounts and } \\
\text { transfer to ZUS;Transfer all individual } \\
\text { accounts back to social security PAYG and } \\
\text { mandatory public NDC; } \\
\text { Option to voluntary contributions to private } \\
\text { funds; }\end{array}$ & $\begin{array}{l}\text { Pension funds must ensure that returns fall within a } \\
\text { band that is defined as the greatest of } 4 \text { percent } \\
\text { points below the weighted-average real rate of } \\
\text { return over the previous } 12 \text { months and } 50 \% \text { of the } \\
\text { weighted-average return; } \\
\text { Available for men } 65+\text { and for women } 60+\text {. In } \\
\text { addition, a means and pension-tested benefit is } \\
\text { provided; } \\
\text { Financed from public funds; }\end{array}$ \\
\hline 11 & Romania & 2004 & 2009 & $\begin{array}{l}2009-2017 \\
2017 \text { - government reduced and froze } \\
\text { contribution } \\
\text { rates to } 2 \text { nd individual account pillar. } \\
\end{array}$ & $\begin{array}{l}2012 \text {-a guarantee fund to protect the second and } \\
\text { the third pillar savings was created; }\end{array}$ \\
\hline 12 & $\begin{array}{l}\text { Ruusia } \\
\text { Federation }\end{array}$ & 2002 & 2012 & $\begin{array}{l}\text { Contributions to individual accounts are } \\
\text { diverted to social insurance } \\
1 \text { st pillar dominant - NDC scheme }\end{array}$ & Basic pension indexed to average wage. \\
\hline 13 & Slovakia & 2005 & 2008 & $\begin{array}{l}2008-2015 \\
\text { Downsizing of individual accounts. } \\
2013 \text { - Contribution rates were reduced from } \\
9 \% \text { to } 4 \% \text {, since } 2017 \text { increase by } 0.25 \% \text { up } \\
\text { to } 6 \% \text { in } 2024 ;\end{array}$ & $\begin{array}{l}2009 \text { - Pension fund management companies are } \\
\text { required to guarantee a zero percent rate of return } \\
\text { every six months; }\end{array}$ \\
\hline 14 & Slovenia & 1999 & 2012 & $\begin{array}{l}\text { Implement PAYG DB pension system. No } \\
\text { mandatory 2nd pillar; }\end{array}$ & $\begin{array}{l}2012 \text { - Social redistribution laws. Solidarity and } \\
\text { minimum pension }\end{array}$ \\
\hline
\end{tabular}

